\title{
Evidence of validity for Socially Skillful Responses Questionnaires - SSRQ-Teachers and SSRQ-Parents
}

\author{
Alessandra Turini Bolsoni-Silva ${ }^{1}$ \\ Sonia Regina Loureiro ${ }^{2}$ \\ ${ }^{1}$ Universidade Estadual Paulista \\ ${ }^{2}$ Universidade de São Paulo
}

\begin{abstract}
There is a lack of free-of-charge validated instruments whereby parents and teachers may be respondents to assess child social skills. Social skills are known to prevent behavioral problems among preschool and school-aged children. This study fills in this gap, the objective of which is to assess the internal consistency and construct and discriminant validity of the Questionários de Respostas Socialmente Habilidosas [Socially Skillful Responses Questionnaire] - teachers' version - SSRQ-Teachers and parents' version - SSRQ-Parents. A total of 134 primary school and preschool teachers and 183 mothers/fathers/caregivers of 88 school-aged children and 95 preschoolers of both sexes participated in the study. In addition to the SSRQ teachers' and parents' versions, the participants completed an additional instrument: the teachers completed the Teacher Report Form - TRF and the parents completed the Child Behavior Checklist (CBCL). The results obtained in the exploratory factor analysis and ROC curve analysis, along with alpha values, indicate good psychometric properties. Thus, the SSRQ-Teachers and SSRQ-Parents presented in this paper are appropriate for assessing both preschool and school-aged children.

Keywords: psychometric; social skills; behavior
\end{abstract}

Evidências de Validade para os Questionários de Respostas Socialmente Habilidosas - QRSH-Pr e QRSH-Pais

Resumo

Verifica-se uma carência de instrumentos validados, de uso livre, tendo pais e professores como respondentes, que avaliem as habilidades sociais infantis, reconhecidas por prevenirem problemas de comportamento de pré-escolares e escolares. O estudo se insere nessa lacuna, tendo por objetivo avaliar a consistência interna, e as evidências de validade de construto e discriminante, relativas aos Questionários de Respostas Socialmente Habilidosas Versão para Professores - QRSH-Pr e para Pais - QRSH-Pais. Participaram 134 professores de crianças escolares e pré-escolares e 183 mães/pais/cuidadores de 88 escolares e de 95 pré-escolares, incluindo meninos e meninas, que além dos respectivos questionários responderam aos professores aos Inventários de Comportamentos da Infância e Adolescência - TRF (Teacher's Report Form) e os pais ao CBCL (Child Behavior Checklist). Os resultados indicaram boas propriedades psicométricas, tendo por suporte os valores do alfa, da análise fatorial exploratória e das análises de Curvas Roc. Considera-se que os instrumentos QRSH-Pr e QRSH-Pais, disponibilizados no artigo, mostraram-se adequados para a avaliação de pré-escolares e escolares.

Palavras-chave: psicometria, habilidades sociais, comportamento

Evidencias de validez para los Cuestionarios de Respuestas Socialmente Habilidosas - QRSH-Pr y QRSH-Pais

\section{Resumen}

Se verifica una falta de instrumentos validados, de uso gratuito, con padres y profesores como encuestados, que evalúan las habilidades sociales infantiles, reconocidas por prevenir problemas de comportamiento de preescolares y escolares. El estudio cae dentro de esta brecha, teniendo como objetivo evaluar la consistencia interna, y las evidencias de validez de constructo y discriminante, relativas a los Cuestionarios de Respuestas Socialmente Habilidosas Versión para Profesores (QRSH-Pr) y para Padres (QRSH-Pais). Participaron 134 profesores de niños escolares y preescolares y 183 madres / padres / cuidadores de 88 escolares y de 95 preescolares, incluyendo niños y niñas, que además de los respectivos cuestionarios los profesores respondieron a los Inventarios de Comportamientos de la Infancia y Adolescencia - TRF (Teacher's Report Form) y los padres al CBCL (Child Behavior Checklist). Los resultados indicaron buenas propiedades psicométricas, teniendo por soporte los valores del alfa, del análisis factorial exploratorio y los análisis de Curvas Roc. Se considera que los instrumentos QRSH-PR y QRSH-Pais, disponibles en el artículo, se mostraron adecuados para la evaluación de preescolares y escolares.

Palabras clave: psicometría; habilidades sociales; comportamiento

\section{Introduction}

Child behavior is recognized as an indicator of child development and studies addressing the behavior of children living in vulnerable conditions are important. Behavioral problems can be classified as internalizing or externalizing (Achenbach \& Rescorla, 2001). Externalizing problems (e.g., aggressiveness, disobedience, opposition) are the problems most frequently mentioned by parents and teachers as being troublesome (Wielewicki, 2011). Internalizing behaviors, which are less frequently studied (Bolsoni-Silva, 
Loureiro \& Marturano, 2016), include shyness, fear, refusal to go to school, anxiety, sorrow, and overattachment (Achenbach \& Rescorla, 2001). Social skills are seen as behaviors that minimize the occurrence of behavioral problems and such a view is supported by correlational studies (Blandon, Calkins, Susan \& Keane, 2010; Pereira, Cia \& Barham, 2008) and studies comparing groups (Bolsoni-Silva \& Loureiro, 2016).

Because children spend most of their time with family or at school, these contexts are the most important sources of socialization, while parents and teachers are the main informants regarding children's behaviors. Parents, especially mothers, spend a great deal of time with their children (Bolsoni-Silva, Figueiredo, Manfrinato \& Marturano, 2006), being primarily responsible for raising, rearing and socializing children. Raising and socializing children imply observing, monitoring, and establishing limits, which make mothers good evaluators of their children's behaviors. In regard to teachers, Bolsoni-Silva et al., (2016b) found accurate correspondence in the reports of teachers collected with the Teacher Report Form (TRF). A correspondence of $75.6 \%$ was found among preschoolers and of $80.35 \%$ was found among school-aged children. Scientific findings, however, show that the perceptions of parents and teachers regarding children's behaviors do not always agree and disparate results are reported.

Studies addressing behavioral problems from the perspectives of teachers and parents (using the TRF and the CBCL, respectively) among low-income community samples report a high occurrence of both externalizing and/or internalizing behavioral problems in different types of disorders, both from the perspectives of parents (56.8\% - Bolsoni-Silva, Levatti, Guidugli \& Marin, 2015) and of teachers (67.7\% - Bolsoni-Silva et al., (2016b). The rate of behavioral problems in community samples is high, which shows the need for validated instruments to identify these children early.

Pereira et al., (2008) addressed a sample of 68 students and found a negative correlation between the total score of social skills (Social Skills Rating System - SSRS-BR) and the scores of internalizing and externalizing behavioral problems (SSRS-BR). Likewise, Blandon et al., (2010) addressed a sample of 253 children and found a negative correlation between social skills (SSRS) and behavioral problems (CBCL).

Based on a predictive longitudinal study, Berry and O'Connor (2010), verified in a sample of 1,364 children that those presenting internalizing problems during kindergarten, and who were monitored up to the $7^{\text {th }}$ grade, scored lower for social skills than their counterparts. The study conducted by Vugt, Deković, Prinzie, Stams and Asscher (2013), which adopted a quasi-experimental design (161 children aged between seven and 13 years old), shows that the training of social skills partly reduced behavioral problems.

In Brazil, Falcão and Bolsoni-Silva (2015), who also adopted a quasi-experimental design, report that children experiencing problems in family and school environments reduced inappropriate responses in both environments after receiving training on social skills, with statistical significance. A study conducted by Bolsoni-Silva and Loureiro (2016) compared children with and without behavioral problems (CBCL and TRF), in a sample of 194 children assessed by their parents and 294 children assessed by teachers, verifying that both groups of respondents considered that preschoolers and schoolaged children with behavioral problems were less socially skillful. Similarly, Barreto, Freitas and Del Prette (2011) addressed a sample of 50 children with behavioral problems and learning difficulties and verified the presence of a considerable deficit in social skills.

Thus, the findings reported in the literature can be summarized as: (a) parents and teachers more frequently disagree in the assessment of behavioral problems of children (Bolsoni-Silva, Figueiredo, Manfrinato \& Marturano, 2006; Korsch \& Petermann, 2014; Lavigne, Dahl, Gouze, LeBailly \& Hopkins, 2014; Rescorla et al., 2014; Rudasill et al., 2014) than agree (Bernerdo, Salas, Fuentes \& García-Martin, 2014; Ercan, Bilaç, Özaslan \& Rohde, 2014). In some studies, teachers more frequently identified problems (e.g., Bolsoni-Silva et al., 2006), while other studies report that parents were the ones who more frequently identified problems (Rescorla et al., 2014), thus, findings are inconsistent; (b) somatic complaints are more frequently reported by parents than teachers (Bernerdo et al., 2014; BolsoniSilva et al., 2006); (c) parents more frequently identify social skills in comparison to teachers (Bolsoni-Silva et al., 2006; Korsch \& Petermann, 2014); and (d) teachers identified social skills that discriminate children with and without behavioral problems more frequently than parents (Bolsoni-Silva \& Loureiro, 2016).

Such disagreements are not likely due to a lack of accuracy in the reports of parents and teachers; rather, they probably occur due to different methods and instruments used to assess children. Additionally, differences in behavior may occur due to the differences in the familial and school environments, such as the requirement of specific tasks and the presence 
of more children/adults or not (Rudasill et al., 2014), so that having the report of both parents and teachers improve understanding of child behaviors.

There are some instruments in Brazil that measure child social skills, such as the Sistema Multimidia de Habilidades Sociais para Crianças [Multimedia System of Social Skills for Children] (SMHSC-Del-Prette, Del Prette \& Del Prette, 2005), the Social Skills Rating System SSRS-BR (Del Prette et al., 2016), and the Questionário de Respostas de Habilidades Sociais Versão para Pais [Socially Skillful Responses Questionnaire], parents' version (SSRQ-Parents - Bolsoni-Silva, Marturano \& Loureiro, 2011) and teachers' version (SSRQ-Teachers - BolsoniSilva, Marturano \& Loureiro, 2009).

The SMHSC-Del-Prette (Del-Prette, Del Prette \& Del Prette, 2005) assesses the social skills of children attending primary school, aged between seven and 12 years old. The children themselves respond to 21 interpersonal situations that require social skills, such as empathy and civility, assertiveness and coping, self-control and participation. The instrument is recommended by the Federal Council of Psychology and presents evidence of validity and reliability. The SMHCSC-Del-Prette, however, does not assess children under the age of seven.

The SSRS-BR can be applied to parents and teachers and also to children aged between six and 13 years old. The instrument was developed in 1990 by Gresham and Elliott (1990) and assesses social skills, behavioral problems and academic performance. The psychometric study conducted by Bandeira, Del Prette, Del Prette and Magalhães (2009), addressing a sample of 416 children (224 boys and 192 girls) attending from the $1^{\text {st }}$ to $4^{\text {th }}$ grades, and 312 parents and 86 teachers, found satisfactory internal consistency and temporal stability. Similarly, the SSRS-BR does not assess children under the age of six.

The SSRQ-Parents adopts a three-point Likert-scale for 18 items addressing social skills that are deemed relevant, such as making requests and properly expressing frustration. This free-of-charge instrument was developed by Bolsoni-Silva, Marturano and Loureiro (2011) and validated among preschoolers with a sample of 131 mothers of 68 boys and 63 girls. The instrument discriminated between children with and without behavioral problems based on the reports of mothers and teachers, respectively (Escala Comportamental Infantil [Child Behavior Scale] - ECI A2 - Graminha, 1994; (Escala Comportamental Infantil - ECI-B - Santos, 2002), presenting an alpha equal to 0.82 .
The SSRQ-Teachers also uses a three-point Likert scale for 24 items addressing social skills. Similar to the parents' version, it is a free-of-charge instrument developed and validated by Bolsoni-Silva, Marturano and Loureiro (2009). A psychometric study addressing the teachers of 260 preschoolers reports good internal consistency (alpha $=0.93$ ) and satisfactory indicators of construct, discriminant and predictive validity, which identified three factors: (a) sociability; (b) initiative, and (c) search for support. The reference used in the aforementioned study was the Escala Comportamental Infantil [Child Behavior Scale] (ECI-B) and discriminated between children with and without behavioral problems. The study verifying predictive validity found that the total score and nine of the items assessed were positively correlated when children attending primary school were reassessed.

The first two instruments that have been mentioned (SMHSC and SSRS-BR) were validated among school-aged children, while the SSRQ-Parents and SSRQ-Teachers were validated among preschoolers. This study is intended to fill in this gap by expanding research that addresses the psychometric properties of the SSRQ-Teachers and SSRQ-Parents, considering the perceptions of both parents and teachers regarding children of both sexes attending preschool and primary schools. Note that further psychometric studies are needed to establish cutoff points that indicate the presence of behavioral problems based on gold-standard instruments, specifically the CBCL and TRF.

\section{Objectives}

To assess internal consistency and evidence of construct and discriminant validity for the Questionários de Respostas Socialmente Habilidosas [Socially Skillful Responses Questionnaires] versions for teachers, SSRQTeachers, and parents, SSRQ-Parents, and estimate cutoff points for indicators of social skills problems as assessed by the SSRQ-Teachers and SSRQ-Parents.

\section{Method}

\section{Ethical Aspects}

This study was approved by the Institutional Review Board at the hosting university. It is part of a larger project titled Saúde, Habilidades Sociais Conjugais e Educativas Parentais: comparações quanto a escolaridade, gênero e problemas de comportamento [Health, Marital Social 
Skills and Parenting Skills: comparisons of education, gender and behavioral problems] (Process No. $5826 / 46 / 01 / 10)$.

\section{Participants}

A total of 72 teachers of 144 school-aged children (from 5 to 10 years old, $M=8.1, S D=1.3$ ) and 62 teachers of 124 preschoolers (from 1 to 6 years old, $M=3.4, S D=1.1)$ took part in this study. The sample of school-aged children comprised 99 boys and 45 girls; 75 of the children presented behavioral problems (52.1\%), according to the TRF. Among the preschoolers, 61 were boys and 63 were girls, $56(45.2 \%)$ of the children presented clinical behavioral problems, according to TRF (Achenbach \& Rescorla, 2001).

A total of 183 mothers/fathers/caregivers of 95 preschoolers (aged from 1 to 6 years old, $M=3.8$; $S D=1.1$ ) and 88 school-aged children (aged from 6 to 10 years old, $M=7.8 ; S D=1.4)$ participated in this study. The sample of mothers/fathers/caregivers of preschoolers provided information for 54 boys and 41 girls, $46(48.22 \%)$ of which presented behavioral problems, based on the CBCL (Achenbach \& Rescorla, 2001). Information regarding the sample of schoolaged children referred to 53 boys and 35 girls, 46 of which were considered to have clinical behavior problems, according to the CBCL (52.3\%).

In regard to demographic characteristics, the preschool teachers were aged 43 years old on average $(S D=5.92)$ and the primary school teachers were aged 36 years old on average $(S D=7.99)$. Only six respondents did not have a bachelor's degree at the time of data collection, while two had attended graduate school.

In regard to the number of schools, $50.5 \%$ of the teachers reported working in only one school; $44.9 \%$ reported working in two schools; and 3.2\% worked in three schools.

The demographic characteristics of the sample of family members were: (a) $83.3 \%$ were mothers, $7.1 \%$ were fathers, and $7 \%$ were caregivers; (b) $78 \%$ of the family respondents reported being in a stable union; $11.9 \%$ were single, $8 \%$ were widowed, and $8.7 \%$ were divorced; (c) in regard to education, $36 \%$ of the sample had (completed or incomplete) primary/middle school, $46 \%$ had (complete or incomplete) high school, and $17.4 \%$ had a bachelor's degree or some undergraduate studies; (d) $50.8 \%$ of the family participants had a paid job; (e) in regard to family income, $13.5 \%$ reported up to one times the minimum wage, while $27.8 \%$ earned two times the minimum wage, $27 \%$ reported earning three times the minimum wage, $11.9 \%$ up to four times the minimum wage, $10.3 \%$ up to five times the minimum wage, and $8.8 \%$ reported earning more than six times the minimum wage; (f) the mothers/fathers/caregivers were aged between 20 and 44 years old, with a mean of 31 years old $(S D=5.69)$.

\section{Instruments $^{1}$}

\section{Teachers}

Teacher's Report Form - TRF (Achenbach \& Rescorla, 2001), an instrument intended to characterize the behaviors of students aged between 6 and 18 years old. It is composed of two parts: the first part includes questions addressing the identification of the child and his/her academic performance, while the second part includes 113 items addressing clinical indicators of behavioral problems. The scores identify general patterns of behavior (externalizing, internalizing and total), which are classified as clinical, borderline, or non-clinical. For this study's purposes, and to organize the groups, the clinical and borderline classifications are grouped together under the clinical label, adopting the criteria suggested by the authors (Achenbach \& Rescorla, 2001). According to Bordin et al., (2013), the TRF is used worldwide to identify mental health disorders among children and adolescents based on information provided by teachers. Its psychometric properties are currently being tested in the Brazilian context.

Questionário de Respostas Socialmente Habilidosas [Socially Skillful Response Questionnaires] (SSRQTeachers- Bolsoni-Silva, Marturano \& Loureiro, 2009) - is an instrument directed to teachers, the objective of which is to identify the social skills of children through 24 questions assessed on a three-point Likert scale ( $2=$ applicable, $1=$ partly applicable; $0=$ not applicable $)$. The authors report that satisfactory internal consistency (alpha $=0.94)$ was obtained among preschoolers, along with positive indicators of predictive validity, while four factors (Sociability, Emotional Expressiveness, Social Initiative, Search for Support and the item does not feel intimidated) explained $62.3 \%$ of the variance. In the aforementioned study, the item "does not feel intimidated" did not load on factors but remained in the

\footnotetext{
QRSH-Parents and QRSH-Teachers are instruments which were applied in a Brazilian population. If readers wish to have access to these instruments in the Portuguese version, please contact the authors of the text directly.
} 
instrument because, from a theoretical point of view, it is a relevant assertive behavior of social skills.

\section{Parents}

Child Behavior Checklist - CBCL, to assess preschoolers and school-aged children from 4 to 18 years of age (Achenbach \& Rescorla, 2001). It is composed of 118 items addressing behavioral problems. The responses of parents to these items show the frequency of responses that indicate externalizing, internalizing and total behavioral problems, resulting in the clinical classification of problems or not. In addition to identifying clinical, borderline, and non-clinical behaviors, this instrument provides the scores for the scales. We adopted criteria suggested by the authors (Achenbach \& Rescorla, 2001) and, for this study's purposes, clinical and borderline classifications are grouped under the clinical label. Bordin, Mari and Caeiro (1995) found satisfactory test-positivity and morbidity criteria for the clinical, borderline and non-clinical profiles.

Questionário de Respostas Socialmente Habilidosas [Socially Skillful Response Questionnaires] (SSRQ-Parents). It is composed of 18 items, with a three-point Likert scale $(2=$ applicable, $1=$ partially applicable; $0=$ not applicable) and assesses the frequency of socially skillful responses, based on the reports of parents (Bolsoni-Silva, Marturano \& Loureiro, 2011). The behaviors assessed include: makes requests, offers help, makes friends, non-verbal interaction, seeks attention, asks questions, greets people, skillfully expresses frustration/displeasure, plays with peers, gives compliments, expresses desires/preferences, expresses affection, uses positive communication, skillfully asserts or expresses rights or needs, is usually in a good mood, skillfully expresses opinions and negotiates or convinces people. The instrument was preliminarily validated among preschoolers by Bolsoni-Silva, Marturano and Loureiro (2011), presenting an alpha of 0.82 and discriminated between children with and without behavioral problems (discriminating validity) based on the perceptions of mothers and teachers and also presented satisfactory concomitant validity with the SSRQ-Teachers.

\section{Data Collection, treatment and analysis}

Prior to data collection, approval was obtained from the Child Education Department of a city in the interior of São Paulo, after which, Early Education Schools and Primary Schools were contacted and received clarification regarding this study's objectives. After the schools' consent, the objectives were also presented to the teachers. Those who agreed signed free and informed consent forms. The teachers were asked to nominate two students under their responsibility: one they considered to have behavioral problems and one they considered not to have behavioral problems. The next step was to contact the families (mothers/father/ caregivers), invite them to participate in the study, and ask their permission for teachers to complete instruments regarding their children. The family members who agreed to participate signed free and informed consent forms and completed the instruments addressing their children's behaviors (CBCL, SSRQ-Parents) in a place convenient for them (at home, at school, or at the university's Applied Psychology Center). The teachers completed the instruments (TRF, SSRQ-Teachers) at school on previously scheduled dates and times.

Data were collected in all the Municipal Primary Schools located in a medium-sized city in the interior of São Paulo, totaling 16 schools from which 287 teachers teaching from the $1^{\text {st }}$ to $5^{\text {th }}$ grades were invited to participate. There are also 38 Municipal Early Education Schools in the same city and data were collected from 16 schools that were located in the same neighborhood where the Primary Schools were located. A total of 224 preschool teachers were invited. A total of 134 teachers agreed to participate: 72 primary school teachers and 62 preschool teachers, equivalent to $26 \%$ of the target population.

All the parents authorized teachers to complete the instruments concerning their children, but only some agreed to actually take part in the study; that is, 183 parents/caregivers (of 88 school-aged children and 95 preschoolers) agreed to participate.

The order in which data were treated was: (a) entering data concerning the CBCL and TRF in the ASEBA software to code the children's behaviors; (b) assigning participants to groups with and without behavioral problems. For a child to be considered to have behavioral problems, whether according to the CBCL or TRF, s/he needed to be classified either as clinical or borderline on at least one of the scales (internalizing, externalizing, total); (c) after exploratory analysis, the alphas of the SSRQ-Teachers and SSRQ-Parents were calculated per factors and for total score; (d) exploratory factor analyses were performed (SSRQ-Teachers and SSRQ-Parents), extracting principal components and varimax rotation; and (e) the ROC curve was calculated for the SSRQ-Teachers and SSRQ-Parents, having the TRF and CBCL as parameters, respectively. The results were organized into 
tables and one figure; the level of significance was established at $5 \%$.

\section{Results}

The results are organized in order to present: (a) the results of Exploratory Factor Analysis and the internal consistency of SSRQ-Teachers (Table 1) and SSRQ-Parents (Table 2); (b) discriminant validity for SSRQ-Teachers (Table 3) and for the SSRQ-Parents
(Table 4); (c) ROC curves for SSRQ-Teachers and SSRQ-Parents (Figure 1).

First, all 24 items of the SSRQ-Teachers and all 18 items of the SSRQ-Parents were considered in the Exploratory Factor Analysis, including both preschoolers and school-aged children. The first factor analysis explained $61.41 \%$ of the variance and identified four factors in the SSRQ-Teachers, while one of these factors included only one item (not being easily intimidated by violent and aggressive children).

Table 1.

Alphas of items and factorial matrix of behavioral categories of the SSRQ-Teachers

\begin{tabular}{|c|c|c|c|}
\hline Categories of the SSRQ-Teachers & $\begin{array}{c}\text { Factor } 1 \\
(14 \text { items })\end{array}$ & $\begin{array}{l}\text { Factor } 2 \\
(5 \text { items })\end{array}$ & $\begin{array}{l}\text { Factor } 3 \\
\text { (4 items) }\end{array}$ \\
\hline Offers help & 0.525 & $(0.342)$ & $(0.320)$ \\
\hline Makes friends & 0.702 & & $(0.302)$ \\
\hline Non-verbal interaction & 0.522 & & $(0.311)$ \\
\hline Greets & 0.648 & & $(0.441)$ \\
\hline Positive relationships & 0.760 & & \\
\hline Expresses frustration & 0.698 & & \\
\hline Plays with peers & 0.547 & & \\
\hline Gives compliments & 0.580 & $(0.353)$ & $(0.357)$ \\
\hline Expresses desires & 0.701 & $(0.341)$ & \\
\hline Expresses affection & 0.576 & & $(0.359)$ \\
\hline Uses positive communication & 0.771 & & \\
\hline Asserts rights & 0.689 & $(0.425)$ & \\
\hline Is usually in a good mood & 0.626 & & \\
\hline Shows interest in others & 0.671 & $(0.424)$ & \\
\hline Takes the initiative & $(0.442)$ & 0.496 & $(0.393)$ \\
\hline Expresses opinions & $(0.345)$ & 0.542 & $\begin{array}{c}( \\
0.523)\end{array}$ \\
\hline Takes part in groups & & 0.742 & \\
\hline Takes part in discussions & $(0.416)$ & 0.742 & \\
\hline Speaks up & & 0.694 & $(0.439)$ \\
\hline Seeks attention & & & 0.786 \\
\hline Asks questions & & $(0.433)$ & 0.626 \\
\hline Makes requests & & & 0.714 \\
\hline Negotiates and convinces & & $(0.454)$ & 0.496 \\
\hline$\%$ of the variance is explained by the factor & 28.826 & 15.607 & 14.780 \\
\hline$\%$ of total accumulated variance & 28.826 & 44.433 & 59.214 \\
\hline \multicolumn{4}{|l|}{$\mathrm{KMO}=0.934$} \\
\hline \multicolumn{4}{|l|}{ Barlett: $p=0.000$} \\
\hline alpha $(23$ items $)=0.944$ & & & \\
\hline
\end{tabular}


Therefore, we opted to exclude this item and perform a new factor analysis, which is presented in Table 1. Something similar happened when responses to the SSRQ-Parents were analyzed. The first factor analysis performed in the sample of preschoolers and schoolaged children, with 18 items, explained $61.31 \%$ and found six factors, three of which had only one item. Thus, these items were excluded (makes requests, greets people, and is usually in a good mood) and a new factor analysis was conducted and is presented in Table 2.

Table 1 shows the three factors identified: the first, named Sociability and Emotional Expressiveness, contains 14 items addressing positive social interactions with teachers, friends and peers, involving communication, the offering of help, expression of affection and expression of rights and frustration. Factor 2 includes five items and was named Social Initiative. It describes behaviors such as taking initiative, expressing opinions, speaking up, and participating in groups, games and discussions in the classroom. Factor 3, with four items, was named Search for Support and addresses items concerning making requests, asking questions, seeking attention, and negotiating. The instrument with 23 items is composed of three factors, which together explain $59.214 \%$ of the variance with an alpha of 0.944 . The KMO and Bartlett statistics are excellent.

Table 2 shows the four factors identified. The first, Social Availability with six items, addresses items such as the search for attention, asking questions, playing with peers, making compliments, taking the initiative, and expressing opinions. Factor 2, named Coping, includes five items that refer to the expression of frustration and desires and asserting rights, in addition to using positive communication and negotiation. Factor 3 Expresses Feelings with two items, refers to non-verbal interaction and expressing affection. Factor 4, named Cooperation, also with two items, includes making requests and offering help. The instrument with 15 items is composed of four factors, which together explain $54.839 \%$ of the

Table 2.

Alpha of items and factorial matrix of behavioral categories of Categories of the SSRQ-Parents

\begin{tabular}{|c|c|c|c|c|}
\hline Categories of the SSRQ-Parents & $\begin{array}{l}\text { Factor } 1 \\
(6 \text { items })\end{array}$ & $\begin{array}{l}\text { Factor } 2 \\
(5 \text { items })\end{array}$ & $\begin{array}{l}\text { Factor } 3 \\
(2 \text { items })\end{array}$ & $\begin{array}{l}\text { Factor } 4 \\
(2 \text { items })\end{array}$ \\
\hline Seeks attention & 0.691 & & & \\
\hline Asks questions & 0.629 & $(0.389)$ & & \\
\hline Play with peers & 0.698 & & & \\
\hline Gives compliments & 0.614 & & & \\
\hline Takes the initiative & 0.603 & & & \\
\hline Expresses opinions & 0.517 & $(0.377)$ & & $(0.436)$ \\
\hline Expresses desires & & 0.588 & & $(0.564)$ \\
\hline Uses positive communication & $(0.343)$ & 0.571 & & $(-0.523)$ \\
\hline Asserts rights & & 0.739 & & \\
\hline Negotiates and convinces & & 0.659 & & \\
\hline Expresses frustration & & 0.644 & & \\
\hline Non-verbal interaction & & & 0.848 & \\
\hline Expresses affection & & & 0.682 & \\
\hline Makes requests & & & $(0.439)$ & 0.520 \\
\hline Offers help & $(0.408)$ & & & 0.462 \\
\hline$\%$ of the variance is explained by the factor & 18.305 & 16.935 & 10.649 & 8.949 \\
\hline$\%$ of total accumulated variance & 18.305 & 35.241 & 45.890 & 54.839 \\
\hline \multicolumn{5}{|l|}{$\mathrm{KMO}=0.793$} \\
\hline \multicolumn{5}{|l|}{ Barlett: $p=0.000$} \\
\hline Alpha (15 items) $=0.790$ & & & & \\
\hline
\end{tabular}


variance and obtained an alpha of 0.790 . KMO statistics is good and Bartlett statistics is excellent.

Table 3 presents the differences between the groups of children with and without behavioral problems according to the perceptions of their teachers. Note that, with the exception of the item seeks attention, which did not present statistical difference, the remaining items and total SSRQ-Teachers obtained the highest mean among children without behavioral problems.

Table 4 shows that seven of the items assessed and the total score discriminated between children with and without behavioral problems according to the perception of parents, namely: gives compliments, expresses desires, takes the initiative, expresses affection, communicates, asserts rights and expresses opinions.

Based on the TRF, figure 1 shows that an area of $0.816(p=0.000)$ was found, with a standard error of 0.026 and confidence interval of $95 \%$ between 0.764 and 0.867 . The cutoff point was between 31.5 and 34.5 , so that scores below 31 indicate behavioral problems.

Considering the SSRQ-Parents, based on the CBCL, the area found was $0.611(p=0.009)$, with a standard error of 0.042 and confidence interval of $95 \%$ between 0.530 and 0.692 . The cutoff point found was the score of 23.5; thus, scores in social skills below 23 indicate behavioral problems.

Table 3.

Discriminating validation of child social skills based on the report of teachers (SSRQ-Teachers)

\begin{tabular}{|c|c|c|c|c|}
\hline \multirow{3}{*}{ Makes requests } & \multirow{2}{*}{\multicolumn{2}{|c|}{$\begin{array}{c}\begin{array}{c}\mathrm{w} / \text { problem } \\
(\mathrm{n}=131)\end{array} \quad \begin{array}{c}\text { w/o problem } \\
(\mathrm{n}=137)\end{array} \\
\text { mean (standard deviation })\end{array}$}} & \multirow{3}{*}{$\frac{t}{-2.693}$} & \multirow{3}{*}{$\frac{p}{0.007^{* *}}$} \\
\hline & & & & \\
\hline & $1.23(0.78)$ & $1.47(0.71)$ & & \\
\hline Offers help & $1.24(0.83)$ & $1.93(0.26)$ & -9.137 & $0.000^{* *}$ \\
\hline Makes friends & $1.54(0.62)$ & $1.90(0.37)$ & -5.714 & $0.000 * *$ \\
\hline Non-verbal interaction & $1.51(0.68)$ & $1.84(0.46)$ & -4.635 & $0.000 * *$ \\
\hline Seeks attention & $1.47(0.76)$ & $1.50(0.68)$ & 2.678 & 0.729 \\
\hline Asks questions & $1.37(0.78)$ & $1.74(0.55)$ & -4.538 & $0.000^{* *}$ \\
\hline Greets & $1.08(0.86)$ & $1.77(0.53)$ & -7.951 & $0.000^{* *}$ \\
\hline Has positive relationships & $1.20(0.80)$ & $1.87(0.40)$ & -8.750 & $0.000^{* *}$ \\
\hline Expresses frustration & $0.76(0.80)$ & $1.73(0.56)$ & -11.462 & $0.000 * *$ \\
\hline Plays with peers & $1.68(0.60)$ & $1.87(0.42)$ & -3.015 & $0.003^{* *}$ \\
\hline Gives compliments & $0.79(0.86)$ & $1.55(0.71)$ & -7.947 & $0.000^{* *}$ \\
\hline Expresses desires & $1.08(0.80)$ & $1.82(0.49)$ & -9.193 & $0.000^{* *}$ \\
\hline Take the initiative & $1.24(0.85)$ & $1.74(0.51)$ & -5.952 & $0.000 * *$ \\
\hline Expresses affection & $1.24(0.75)$ & $1.80(0.52)$ & -7.115 & $0.000 * *$ \\
\hline Uses positive communication & $1.32(0.72)$ & $1.88(0.37)$ & -8.019 & $0.000 * *$ \\
\hline Asserts own rights & $0.98(0.82)$ & $1.79(0.51)$ & -9.677 & $0.000^{* *}$ \\
\hline Is usually in a good mood & $1.33(0.74)$ & $1.94(0.24)$ & -9.244 & $0.000^{* *}$ \\
\hline Expresses opinions & $1.31(0.83)$ & $1.74(0.55)$ & -5.049 & $0.000 * *$ \\
\hline Negotiates and convinces & $0.86(0.87)$ & $1.16(0.80)$ & -2.931 & $0.004^{* *}$ \\
\hline Takes part in groups & $1.48(0.67)$ & $1.88(0.42)$ & -5.899 & $0.000^{* *}$ \\
\hline Takes part of discussions & $1.03(0.85)$ & $1.74(0.57)$ & -8.017 & $0.000^{* *}$ \\
\hline Speaks up & $1.12(0.87)$ & $1.47(0.79)$ & -3.40 & $0.001 * *$ \\
\hline Shows interest in others & $0.86(0.77)$ & $1.72(0.57)$ & -10.436 & $0.000 * *$ \\
\hline Total score & $26.85(10.92)$ & $38.12(6.73)$ & -10.223 & $0.000^{* *}$ \\
\hline
\end{tabular}

$\mathrm{p} \leq 0.01 * *, \mathrm{p} \leq 0.05^{*}$ 
Table 4.

Discriminant validation of child social skills based on the report of parents (SSRQ-Parents)

\begin{tabular}{|c|c|c|c|c|}
\hline \multirow{3}{*}{ Makes requests } & $\begin{array}{c}\mathrm{w} / \text { problem } \\
(\mathrm{n}=92)\end{array}$ & $\begin{array}{c}\text { w/o problem } \\
\quad(\mathrm{n}=91)\end{array}$ & \multirow{3}{*}{$\frac{t}{1.410}$} & \multirow{3}{*}{$\frac{p}{0.160}$} \\
\hline & \multicolumn{2}{|c|}{ Mean (standard deviation) } & & \\
\hline & $1.77(0.49)$ & $1.66(0.58)$ & & \\
\hline Offers help & $1.68(0.61)$ & $1.71(0.50)$ & -0.358 & 0.721 \\
\hline Non-verbal interaction & $1.73(0.61)$ & $1.81(0.47)$ & -1.051 & 0.294 \\
\hline Seeks attention & $1.84(0.45)$ & $1.85(0.39)$ & -0.147 & 0.883 \\
\hline Asks questions & $1.74(0.57)$ & $1.79(0.48)$ & -0.665 & 0.507 \\
\hline Expresses frustration & $1.33(0.87)$ & $1.56(0.70)$ & -1.854 & 0.065 \\
\hline Plays with peers & $1.89(0.35)$ & $1.97(0.18)$ & -1.854 & 0.065 \\
\hline Gives compliments & $1.53(0.75)$ & $1.79(0.48)$ & -2.775 & 0.006 \\
\hline Expresses desires & $1.58(0.73)$ & $1.79(0.51)$ & -2.315 & $0.022 *$ \\
\hline Takes the initiative & $1.43(0.70)$ & $1.70(0.57)$ & -2.848 & $0.005^{* *}$ \\
\hline Expresses affection & $1.91(0.32)$ & $1.99(0.10)$ & -2.155 & $0.033^{*}$ \\
\hline Uses positive communication & $1.79(0.48)$ & $1.95(0.23)$ & -2.715 & $0.007 * *$ \\
\hline Asserts own rights & $1.41(0.79)$ & $1.69(0.51)$ & -2.847 & $0.005^{* *}$ \\
\hline Expresses opinions & $1.46(0.79)$ & $1.68(0.59)$ & -2.116 & $0.036^{*}$ \\
\hline Negotiates and convinces & $1.36(0.83)$ & $1.53(0.67)$ & -1.507 & 0.134 \\
\hline Total score & $24.45(5.05)$ & $26.47(3.29)$ & -3.210 & $0.002^{* *}$ \\
\hline
\end{tabular}

$\mathrm{p} \leq 0.01^{* *}, \mathrm{p} \leq 0.05^{*}$

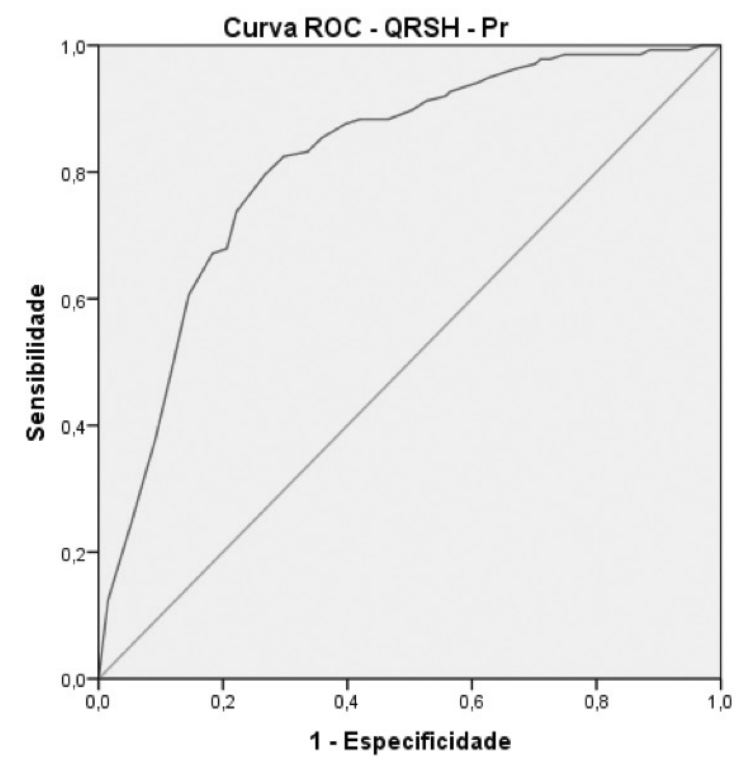

Os segmentos diagonais såo produzidos por vínculos.

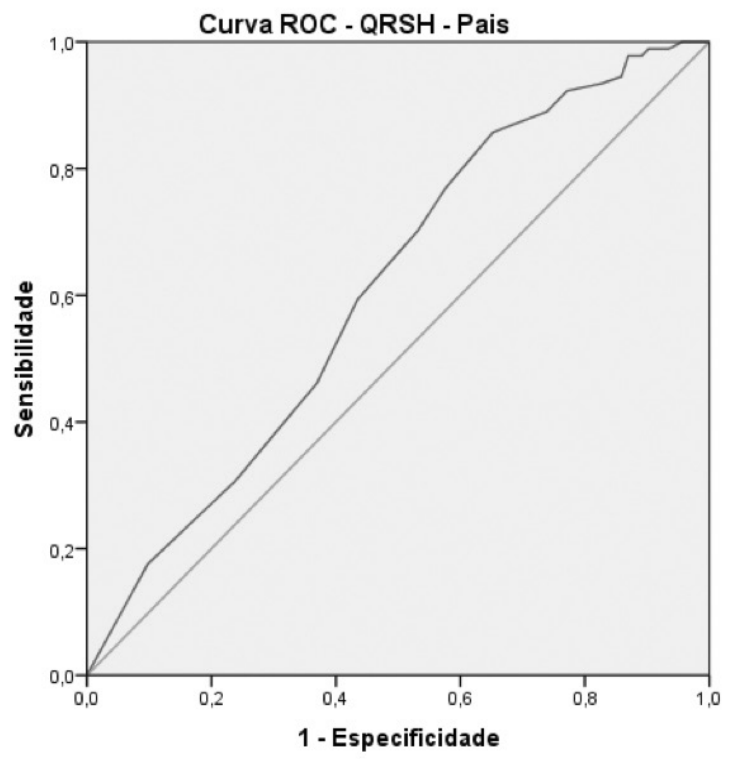

Os segmentos diagonais são produzidos por vínculos.

Figure 1. ROC curves of the SSRQ-Teachers and SSRQ-Parents 


\section{Discussion}

This study presents the reformulated versions of the SSRQ-Parents and SSRQ-Teachers (Annexes 1 and 2) after assessing psychometric properties among preschool and school-aged boys and girls, taking into account the reports of mothers/fathers/caregivers and teachers. The questionnaires assess the social skills of children aged from 1 to 10 years old and the behaviors assessed are in agreement with the literature addressing social skills (Blandon, Calkins, Susan \& Keane, 2010; Bolsoni-Silva \& Loureiro, 2016; Bolsoni-Silva et al., 2016a; Del Prette et al., 2016; Pereira et al., 2008) concerning communication, affection, and coping, which indicate the relationship established with adults and peers in the familial and school environments.

Psychometric studies expand on prior studies addressing these instruments (Bolsoni-Silva et. al, 2009; Bolsoni-Silva et. al, 2011) in terms of broadening the ages of the children assessed, from really young to up 10 years old, already attending primary school. The remaining instruments assessing social skills (SMHSCDel-Prette, Del Prette \& Del Prette, 2005; Social Skills Rating System - SSRS-BR, Del Prette et al., 2016) have not yet presented evidence of validity among young children; thus, this study fills in this gap.

Only one item (i.e., not easily intimidated by violent or aggressive children) was removed from the original teachers' version, which retained 23 items. Note that in the first study addressing this instrument, this item loaded alone on one factor. Thus, in this study we opted to exclude it and three factors were found that loaded in a manner very similar to the original study (BolsoniSilva et al., 2009). Only three items were assigned to factors (provides help, takes part in groups, and negotiates/convinces), contrasting with those in which they were originally assigned in the previous study, possibly because in this study's sample both preschool and school-aged children were included. Given the similarity of current results, however, we opted to keep the names: (a) Factor 1: Sociability and Emotional Expressiveness, with 14 items concerning positive social interaction with teachers, friends and peers, involving communication, offering help, expressing affection and asserting rights and expressing frustration; (b) Factor 2: Social initiative, with five items that refer to behaviors such as taking initiative, expressing opinions, speaking up, and taking part in groups, games and discussions in the classroom; (c) Factor 3: Search for Support, which refers to items such as making requests, asking questions, seeking attention, and negotiating. Factor loading obtained by items ranged from 0.542 to 0.771 , which is very high, as was also observed in the original study (Bolsoni-Silva et. al, 2009). KMO statistics equal to 0.934, Bartlett's statistics of $p=0.000$, variance of $59.214 \%$, and alpha equal to 0.944 all indicate the instrument is appropriate and presents high internal consistency, maintaining the psychometric properties of the original study, while it was expanded to children attending primary school.

After the analysis addressing validity, the parents' version retained 15 of the 18 original items (items makes requests, greets people, and is usually in a good mood were excluded) organized into four factors. Exploratory factor analysis was not conducted in the previous study addressing evidence of validity for the SSRQ-Parents, thus we could only verify that 15 of the 18 items loaded into four factors in this study. The factors are: (a) Factor 1 Social Availability, with six items refers to seeks attention, asks questions, plays with peers, gives compliments, takes initiative, and expresses opinions; (b) Factor 2, Coping has five items and includes expresses frustration and desires and asserts rights, in addition to using positive communication and negotiation; (c) Factor 3 Expressesfeelings has two items, non-verbal interaction and expresses affection; (d) Factor 4 Cooperation also has two items, making requests and offering help. The previous study addressing the SSRQ-Parents (Bolsoni-Silva et. al, 2009) did not report construct validity; doing so is an advantage of this study. Additionally, factor loadings ranged from 0.571 to 0.739 , considered to be high, with KMO statistics equal to 0.793, Bartlett's statistics of $p=0.000$, a variance of $54.839 \%$ and alpha equal to 0.790 , that is, the instrument presents appropriate psychometric properties.

These instruments were able to discriminate between children with and without behavioral problems, which is shown by the analysis of the ROC curve, based on instruments widely used in the literature and considered to be gold standards for assessing behavioral problems from the perspective of teachers and parents (TRF and CBCL, respectively). Previous studies (Bolsoni-Silva et al., 2009; Bolsoni-Silva et al., 2011) using screening instruments were able to discriminate between children with and without behavioral problems. This study, in turn, enabled establishing cut off points to indicate behavioral problems, which can facilitate the early identification of children experiencing vulnerabilities and at risk of developing behavior problems, a situation that has been found frequently among children in the community (Bolsoni-Silva, et al., 2015; Bolsoni-Silva et al, 2016b) and is consistent with 
situations faced by children referred to care services (Wielewicki, 2011). Thus, the free-of-charge SSRQParents and SSRQ-Teachers can be applied by any healthcare or educational worker to screen for behavioral difficulties early on and can also be used before and after interventions.

Note that, in agreement with the literature, fathers/ mothers/caregivers present different perceptions of children's social skills (Bolsoni-Silva, Figueiredo, Manfrinato \& Marturano, 2006; Korsch \& Petermann, 2014; Lavigne et al., 2014; Rescorla et al., 2014; Rudasill et al., 2014); that is, families tend to assess the behaviors of children more positively than teachers (Bolsoni-Silva et al., 2006; Bolsoni-Silva \& Loureiro, 2016; Korsch \& Petermann, 2014). A larger number of behaviors were identified in school discriminating between children with and without behavioral problems, while families tend to more frequently identify social skills even among children presenting behavioral problems. This finding confirms that the familial environment differs from the school environment, as children at school are required to learn appropriate behavior to ensure their socioemotional development. Applying instruments to families and teachers is relevant to expanding the identification of children's difficulties and resources, favoring greater understanding of their behaviors and verifying whether problems are presented in one of the environments or in both. Recognizing this facilitates the indication of specific and preventive measures or interventions in accordance with the severity of problems. Additional assessments are suggested to investigate interactions between teachers and students, families and children, and include instruments that assess behavioral problems as a resource with specific indications based on screening for problems.

\section{Final Considerations}

This study presents the instruments SSRQ-Parents and SSQR-Teachers, which are free-of-charge and easy to apply to rapidly identify children experiencing social vulnerability and/or requiring psychological treatment. These instruments also enable systematizing information regarding children who had already been referred to screening services in university clinics or healthcare facilities. The conclusion is that the SSRQ-Parents and SSRQ-Teachers present good psychometric properties in terms of construct and discriminant validity, along with internal consistency, being appropriate to assess preschool and school-aged children of both sexes.
This study's limitations include its relatively small sample and the need for other psychometric studies, including confirmatory factor analysis and observational measurement, aspects that can be the object of future research. Further studies should also include samples from different regions of Brazil and children attending private schools. Because the reports of parents and teachers may be influenced by other variables, such as social desirability, the interaction between parents and children and between teachers and students should be observed in both structured and non-structured situations, which could be useful to expanding the description of child social skills and be the object of future research.

\section{References}

Achenbach, T. M., \& Rescorla, L. A (2001). Manual for the ASEBA School-Age Forms \& Profiles. Burlington, VT: University of Vermont, Research Center for Children, Youth, \& Families.

Bandeira, M., Del Prette, Z. A. P., Del Prette, A., \& Magalhães, T. (2009). Validação das Escalas de Habilidades Sociais, Comportamentos Problemáticos e Competência Acadêmica (SSRS-BR) para o Ensino Fundamental. Psicologia: Teoria e Pesquisa, 25(2), 271-282. doi:10.1590/S0102-37722009000200016.

Barreto, S. O., Freitas, L. C., \& Del Prette, Z. A. P. (2011). Habilidades sociais na comorbidade entre dificuldades de aprendizagem e problemas de comportamento: uma avaliação multimodal. Psico, 42(4), 503-510. Recuperado de http://revistaseletronicas.pucrs.br/ojs/index.php/revistapsico/ article/view/7593/7457.

Bernerdo, I. M., Salas, M. D., Fuentes, M. J., \& García-Martin, M. A. (2014). Foster children's behavior problems and impulsivity in the family and school context. Children and Youth Services Review, 42, 43-49. doi: 10.1016/j.childyouth.2014.03.022.

Berry, D., \& O’Connor, E. (2010). Behavioral risk, teacher-child relationships, and social skill development across middle childhood: A child-by-environment analysis of change. Journal of Applied Developmental Psychology, 31(2010), 1-14. doi: 10.1016/j. appdev.2009.05.001.

Blandon, A. Y., Calkins, S. D., \& Keane, S. P. (2010). Predicting emotional and social competence during early childhood from toddler risk and maternal 
behavior. Development and Psychopathology, 22(1), 119132. doi: 10.1017/S0954579409990307.

Bolsoni-Silva, A. T. Marturano, E. M, \& Loureiro, S. R. (2011). Estudos de confiabilidade e validade do questionário de respostas socialmente habilidosas versão para pais - QRSH-Pais. Psicologia: Reflexão e Crítica, 24(2), 1-9. doi: 10.1590/ S0102-79722011000200003.

Bolsoni-Silva, A. T., \& Loureiro, S. R. (2016). Simultaneous assessement of social skills and behavior problems: Education and gender. Estudos de Psicologia (Campinas), 33(3), 453-464. doi: 10.1590/1982-02752016000300009.

Bolsoni-Silva, A. T., Figueiredo, V. A. P., Manfrinato, J. W. S., \& Marturano, E. M. (2006). Habilidades Sociais e Problemas de Comportamento de Pré-Escolares: Comparando Avaliações de Mães e de Professoras. Psicologia: Reflexão e Crítica, 19(3), 460469. doi: 10.1590/S0102-79722006000300015.

Bolsoni-Silva, A. T., Levatti, G. E., Guidugli, P. M., \& Marin, V. C. M. (2015). Problemas de comportamento, em ambiente familiar em escolares e pré-escolares diferenciados pelo sexo. Revista Interamericana de Psicologia/Interamerican Journal of Psychology (IJP), 49(3), 354-364. Recuperado de: https://journal.sipsych.org/index.php/IJP/article/ view/72/pdf.

Bolsoni-Silva, A. T., Loureiro, S. R., \& Marturano, E. M. (2009). Contribuições para a construção e validação do Questionário de Respostas Socialmente Habilidosas: versão para Professores - QRSH-PR. Spanish Journal of Psychology, 12(1), 349-359. doi: 10.1017/S1138741600001748.

Bolsoni-Silva, A. T., Loureiro, S. R., \& Marturano, E. M. (2016a). Comportamentos internalizantes: associações com habilidades sociais, práticas educativas, recursos do ambiente familiar e depressão materna. Psico (Porto Alegre), 47 (2), 111-120. doi: 10.15448/1980-8623.2016.2.20806.

Bolsoni-Silva, A. T., Silveira, A. M., Cunha, E. V., da Silva, L. L., \& Orti, N. P. (2016b). Problemas de comportamento e funcionamento adaptativo no Teacher's Report Form (TRF): comparações por gênero e escolaridade. Gerais: Revista Interinstitucional de Psicologia, 9(1), 141-155. Recuperado de: http://www.fafich.ufmg.br/gerais/index.php/ gerais/article/view/542/416.
Bordin, I. A., Rocha, M. M., Paula, C. S., Teixeira, M. C. T. V., Achenbach, T. M., Rescorla, L. A., \& Silvares, E. F. M. (2013). Child Behavior Checklist (CBCL), Youth Self-Report (YSR) and Teacher's Report Form(TRF): an overview of the development of the original and Brazilian versions. Cadernos de Saúde Pública, 29(1), 3-13. doi: 10.1590/ S0102-311X2013000100004.

Del Prette, Z. A. P., \& Del Prette, A. (2005). Sistema multimidia de habilidades sociais para crianças (SMHSC-DEL-PRETTE) e Inventário multimídia de habilidades sociais para crianças (IMHSC-DEL-PRETTE). São Paulo: Casa do Psicólogo.

Del Prette, Z. A. P., Freitas, L. C., Bandeira, M., \& Del Prette, A. (2016). SSRS - Inventário de Habilidades Sociais, Problemas de Comportamento e Competência Acadêmica para Crianças - Kit Completo. São Paulo: Casa do Psicólogo.

Ercan, E. S., Bilaç, Ö., Özaslan, T. U., \& Rohde, L. A. (2015). Is the prevalence of ADHD in Turkish elementary school children really high? Social Psychiatry and Psychiatric Epidemiology, 50(7), 1145-1152. doi: 10.1007/s00127-015-1071-9.

Falcão, A. F., \& Bolsoni-Silva, A. T. (2015). Intervention in Social Skills: The Behavior of Children from the Perspective of Parents and Teachers. British Journal of Education, Society \& Behavioural Science, 11(3), 1-18. doi: https://doi.org/10.9734/ BJESBS/2015/20033.

Graminha, S. S. V. (1994). A Escala Comportamental Infantil de Rutter A2: Estudos de adaptação e fidedignidade. Estudos de Psicologia (Campinas), 11(3), 34-42.

Gresham, F. M., \& Elliott, S. N. (1990). Social Skills Rating System (SSRS). Circle Pines, MN: American Guidance Service.

Korsch, F., \& Petermann, F. (2014). Agreement Between Parents and Teachers on Preschool Children's Behavior in a Clinical Sample with Externalizing Behavioral Problems. Child Psychiatry Human Development, 45(5), 617-627. doi: 10.1007/ s10578-013-0430-6.

Lavigne, J. V., Dahl, K. P., Gouze, K. R., LeBailly, S. A., \& Hopkins, J. (2015). Multi-Domain Predictors of Oppositional Defiant Disorder Symptoms in Preschool Children: Cross-Informant Differences. 
Child Psychiatry Human Development, 46(2), 308-319. doi: 10.1007/s10578-014-0472-4.

Pereira, C. S., Cia, F., \& Barham, E. J. (2008). Autoconceito, habilidades sociais, problemas de comportamento e desempenho acadêmico na puberdade: inter-relações e diferenças entre sexos. Interação em Psicologia, 12(2), 203-213. doi: 10.5380/ psi.v12i2.7870.

Rescorla, L. A., Bochicchio, L., Achenbach, T. M., Ivanova, M. Y., Almqvist, F., Begovac, I., \& Verhulst, F. C. (2014). Parent-Teacher Agreement on Children's Problems in 21 Societies. Journal of Clinical Child \& Adolescent Psychology, 43(4), 627-642. doi: 10.1080/15374416.2014.900719.

Rudasill, K. M., Prokasky, A., Tu, X., Frohn, S., Sirota, K., \& Molfese, V. J. (2014). Parent vs. teacher ratings of children's shyness as predictors of language and attention skills. Learning and Individual Differences, 34, 57-62. doi: 10.1016/j.lindif.2014.05.008.
Santos, P. L. (2002). Riscos e recursos em crianças com alto e baixo rendimento acadêmico: Um estudo comparativo (Tese de Doutorado não-publicada). Faculdade de Filosofia, Ciências e Letras de Ribeirão Preto, Universidade de São Paulo, Ribeirão Preto, SP.

Vugt, E. S., Deković, M., Prinzie, P., Stams, G. J. J. M., \& Asscher, J. J. (2013). Evaluation of a group-based social skills training for children with problem behavior. Children and Youth Services Review 35(1), 162-167. doi: 10.1016/j.childyouth.2012.09.022.

Wielewicki, A. (2011). Problemas de comportamento infantil: importância e limitações de estudos de caracterização em clínicas-escola brasileiras. Temas em Psicologia, 19(2), 379-389. Recuperado de: http://pepsic.bvsalud.org/scielo.php?script $=$ sci_ arttext\&pid $=$ S1413-389X2011000200003\&lng=pt \&nrm $=$ iso\&tlng $=$ pt.

Recebido em: 07/06/2017

Reformulado em: 06/10/2018,13/02/2019

Aceito: 24/03/2019 


\section{Annex 1 \\ Socially Skillful Responses Questionnaire - Teachers (SSRQ-Teachers)}

\section{Instructions to the interviewer:}

The interviewer describes the characteristics of the instrument to the respondent, instructing him/her to answer according to orientations provided in item Instructions for the respondent, and asks the respondent to report information required in the item Child Characterization. Afterwards, the interviewer reads the questions (paraphrasing whenever necessary to ensure the respondent's full understanding), for instance: "Does the child makes requests?" If the respondent answers positively, ask the frequency such behavior occurs to determine whether it "certainly applies", "somewhat applies" or "does not apply". The interviewer takes notes of the respondent's answers. Answers of "certainly applies" are scored 2; answers of "somewhat applies" are scored 1; and answers of "does not apply" are scored 0.

\section{Child characterization:}

Child's name and age:

School:

Teacher:

\section{Instructions for the respondent:}

Below is a list of behaviors frequently presented by children. If the child certainly presents the behavior described, please answer "certainly applies" but if the child presents the behavior but not very frequently, please answer "somewhat applies". If, to your best knowledge, the child does not present the behavior described, please answer "does not apply".

\begin{tabular}{|c|c|c|c|}
\hline BEHAVIORS & $\begin{array}{l}\text { Does not } \\
\text { apply }\end{array}$ & $\begin{array}{l}\text { Somewhat } \\
\text { applies }\end{array}$ & $\begin{array}{c}\text { Certainly } \\
\text { applies }\end{array}$ \\
\hline \multicolumn{4}{|l|}{ Does the child make requests? } \\
\hline \multicolumn{4}{|l|}{ Does the child help the teacher and peers? } \\
\hline \multicolumn{4}{|l|}{ Does the child make friends? } \\
\hline \multicolumn{4}{|l|}{ Does the child interact non-verbally with familiar people by smiling, gesturing? } \\
\hline \multicolumn{4}{|l|}{ Does the child seek your attention? } \\
\hline \multicolumn{4}{|l|}{ Does the child ask questions? } \\
\hline \multicolumn{4}{|l|}{ Does the child greet people? } \\
\hline \multicolumn{4}{|l|}{$\begin{array}{l}\text { Does the child establish positive relationships with one or more friends, } \\
\text { showing concern for them? }\end{array}$} \\
\hline \multicolumn{4}{|l|}{$\begin{array}{l}\text { Does the child appropriately express frustration and displeasure without } \\
\text { harming others? }\end{array}$} \\
\hline \multicolumn{4}{|l|}{ Does the child play with peers? } \\
\hline \multicolumn{4}{|l|}{ Does the child give compliments? } \\
\hline \multicolumn{4}{|l|}{ Does the child appropriately express desires and preferences? } \\
\hline \multicolumn{4}{|l|}{ Does the child take the initiative? } \\
\hline \multicolumn{4}{|l|}{ Does the child express affection? } \\
\hline \multicolumn{4}{|l|}{ Does the child positively communicate with people? } \\
\hline \multicolumn{4}{|l|}{ Does the child appropriately express rights and needs? } \\
\hline \multicolumn{4}{|l|}{ Is the child usually in a good mood? } \\
\hline \multicolumn{4}{|l|}{ Does the child express opinions? } \\
\hline \multicolumn{4}{|l|}{ Does the child negotiate and convince other people of her/his points of view? } \\
\hline \multicolumn{4}{|l|}{ Does the child take part in games and schoolwork in classroom? } \\
\hline \multicolumn{4}{|l|}{ Does the child take part in discussions, providing relevant contributions? } \\
\hline \multicolumn{4}{|l|}{ Does the child easily speak up? } \\
\hline $\begin{array}{l}\text { Does the child show interest in others, change opinions and appropriately } \\
\text { accept information from others? }\end{array}$ & & & \\
\hline
\end{tabular}




\section{Annex 2 \\ Socially Skillful Responses Questionnaire - Parents (SSRQ-Parents)}

\section{Instructions to the interviewer:}

The interviewer describes the characteristics of the instrument to the respondent, instructing him/her to answer according to orientations provided in item Instructions for the respondent, and asks the respondent to report information required in the item Child Characterization. Afterwards, the interviewer reads the questions (paraphrasing whenever necessary to ensure the respondent's full understanding) for instance: "Does the child makes requests?" If the respondent answers positively, ask the frequency such behavior occurs to determine whether it "certainly applies", "somewhat applies" or "does not apply". The interviewer takes notes of the respondent's answers. Answers of "certainly applies" are scored 2; answers of "somewhat applies" are scored 1; and answers of "does not apply" are scored 0.

\section{Child characterization:}

Child's name and age:

School:

Teacher:

Instructions for the respondent:

Below there is a list of behaviors frequently presented by children. If the child certainly presents the behavior described, please answer "certainly applies," but if the child presents the behavior but not very frequently, please answer "somewhat applies". If, to your best knowledge, the child does not present the behavior described, please answer "does not apply".

\begin{tabular}{|c|c|c|c|}
\hline BEHAVIORS & $\begin{array}{l}\text { Does not } \\
\text { apply }\end{array}$ & $\begin{array}{l}\text { Somewhat } \\
\text { applies }\end{array}$ & $\begin{array}{l}\text { Certainly } \\
\text { applies }\end{array}$ \\
\hline \multicolumn{4}{|l|}{ Does the child offer help? } \\
\hline \multicolumn{4}{|l|}{ Does the child make friends? } \\
\hline \multicolumn{4}{|l|}{$\begin{array}{l}\text { Does the child interact non-verbally with familiar people by smiling, } \\
\text { gesturing? }\end{array}$} \\
\hline \multicolumn{4}{|l|}{ Does the child seek your attention? } \\
\hline \multicolumn{4}{|l|}{ Does the child make questions? } \\
\hline \multicolumn{4}{|c|}{$\begin{array}{l}\text { Does the child appropriately express frustration and displeasure without } \\
\text { harming others? }\end{array}$} \\
\hline \multicolumn{4}{|c|}{ Does the child play with peers? } \\
\hline \multicolumn{4}{|l|}{ Does the child give compliments? } \\
\hline \multicolumn{4}{|l|}{ Does the child appropriately express desires and preferences? } \\
\hline \multicolumn{4}{|l|}{ Does the child take the initiative? } \\
\hline \multicolumn{4}{|l|}{ Does the child express affection? } \\
\hline \multicolumn{4}{|l|}{ Does the child use positive communication with people? } \\
\hline \multicolumn{4}{|l|}{ Does the child appropriately express rights and needs? } \\
\hline \multicolumn{4}{|l|}{ Does the child express opinions? } \\
\hline Does the child negotiate and appropriately convince people? & & & \\
\hline
\end{tabular}


About the authors:

Alessandra Turini Bolsoni-Silva is Psychologist, Master's Degree in Special Education by Federal University of São Carlos and Ph.D. in Psychology by University of São Paulo. Professor in the undergraduate course in Psychology and Graduate Program in Psychology of Development and Learning in São Paulo State University, Bauru. She acts in Applied Behavior Analysis in Clinic Psychology and Development Psychology, working with several themes concerning assessment and intervention in social skills.

ORCID: https://orcid.org/0000-0001-8091-9583

E-mail:bolsoni.silva@unesp.br

Sonia Regina Loureiro is a psychologist, Master and PhD in Clinical Psychology from the University of São Paulo, professor at the Medical School at Ribeirão Preto/USP, advisor in the Graduate Programs in Psychology at the FFCLRP- USP and in Mental Health at FMRP-USP. Dr. Loureiro works with research using instruments and assessment procedures in different psychosocial contexts.

ORCID: https://orcid.org/0000-0001-9423-2897

E-mail: srlourei@fmrp.usp.br

Contact:

Alessandra Turini Bolsoni-Silva

Departamento de Psicologia

Faculdade de Ciências - UNESP - Campus de Bauru

Av. Eng. Luiz Edmundo Carrijo Coube, 14-01 - Vargem Limpa

Bauru-SP, Brasil

CEP: $17033-360$

Fone: (14) 3103-6087 